\title{
Phosphorus cycling in the red tide incubator region of Monterey Bay in response to upwelling
}

\author{
Katherine R. M. Mackey ${ }^{1}{ }^{*}$, Cécile E. Mioni ${ }^{2}$, John P. Ryan ${ }^{3}$ and Adina Paytan ${ }^{2}$ \\ ${ }^{1}$ Marine Chemistry and Geochemistry, Woods Hole Oceanographic Institution, Woods Hole, MA, USA \\ 2 Institute of Marine Science, University of California, Santa Cruz, CA, USA \\ ${ }^{3}$ Monterey Bay Aquarium Research Institute, Moss Landing, CA, USA
}

\section{Edited by:}

Sonya Dyhrman, Woods Hole

Oceanographic Institution, USA

\section{Reviewed by:}

Lisa Moore, University of Southern

Maine, USA

Bethany Jenkins, University of Rhode

Island, USA

Jason B. Sylvan, University of

Southern California, USA

${ }^{*}$ Correspondence:

Katherine R. M. Mackey, Marine Chemistry and Geochemistry, Woods Hole Oceanographic Institution, Woods Hole, MA 02543, USA.

e-mail: mackeykrm@gmail.com
This study explores the cycling of phosphorus $(\mathrm{P})$ in the euphotic zone following upwelling in northeastern Monterey Bay (the Red Tide Incubator region) of coastal California, with particular emphasis on how bacteria and phytoplankton that form harmful algal blooms mediate and respond to changes in $\mathrm{P}$ availability. In situ measurements of nutrient concentrations, phytoplankton community composition, and cell-specific alkaline phosphatase (AP) activity (determined via enzyme-labeled fluorescence assay) were measured during three cruises. Upwelling led to a 10 -fold increase in dissolved inorganic (DIP) in surface waters, reaching $\sim 0.5 \mu \mathrm{mol} \mathrm{L}^{-1}$. This DIP was drawn down rapidly as upwelling relaxed over a period of 1 week. Ratios of nitrate to DIP drawdown ( $5: 1$, calculated as the change in nitrate divided by the change in DIP) were lower than the Redfield ratio of 16:1, suggesting that luxury $\mathrm{P}$ uptake was occurring as phytoplankton bloomed. Dissolved organic (DOP) remained relatively constant $\left(\sim 0.3 \mu \mathrm{mol} \mathrm{L}^{-1}\right)$ before and immediately following upwelling, but doubled as upwelling relaxed, likely due to phytoplankton excretion and release during grazing. This transition from a relatively high DIP:DOP ratio to lower DIP:DOP ratio was accompanied by a decline in the abundance of diatoms, which had low AP activity, toward localized, spatially heterogeneous blooms of dinoflagellates in the genera Prorocentrum, Ceratium, Dinophysis, Alexandrium, and Scrippsiella that showed high AP activity regardless of ambient DIP levels. A nutrient addition incubation experiment showed that phytoplankton growth was primarily limited by nitrate, followed by DIP and DOP, suggesting that $P$ regulates phytoplankton physiology and competition, but is not a limiting nutrient in this region. AP activity was observed in bacteria associated with lysed cell debris and aggregates of particulate organic material, where it may serve to facilitate $P$ regeneration, as well as affixed to the surfaces of intact phytoplankton cells, possibly indicative of close, beneficial phytoplankton-bacteria interactions.

Keywords: phosphorus cycle, upwelling, red tide, harmful algal bloom, alkaline phosphatase, Monterey Bay

\section{INTRODUCTION}

Coastal regions cover less than $15 \%$ of the ocean's surface, yet they contribute nearly half of the ocean's primary productivity (Wollast, 1991). The high productivity of coastal waters is due in part to their proximity to land, where inputs from rivers, atmospheric deposition, and groundwater can all transport terrestrial nutrients from the Earth's crust into the ocean. However, a large portion $(\sim 50 \%)$ of coastal productivity is attributable to upwelling in eastern boundary current regions (Chavez and Toggweiler, 1995). Coastal upwelling brings nutrient rich deep water to the surface ocean where it supports phytoplankton growth, thereby influencing the carbon (C) cycle and forming the base of marine food webs. Harmful algal blooms (HABs), such as red tides, can also occur in coastal waters and may be controlled by excessive nutrient input or unbalanced nutrient stoichiometry.

Historically much emphasis has been placed on the availability of nitrogen $(\mathrm{N})$ in controlling marine productivity (Dugdale and Goering, 1967; Falkowski, 1997). This is particularly true of coastal upwelling regions, where productivity is strongly correlated with $\mathrm{N}$ availability (Chavez and Messie, 2009) and phytoplankton grow out experiments can point to $\mathrm{N}$ limitation even when ambient $\mathrm{N}$ concentrations are high (Kudela and Dugdale, 2000; Mackey et al., 2010). However, a growing body of literature suggests that phosphorus (P) availability also exerts influence on phytoplankton dynamics in coastal waters (Sylvan et al., 2006). Dissolved inorganic P (DIP) has been identified as a limiting nutrient along the southern coast of China (Harrison et al., 1990), the eastern Mediterranean Sea (Krom et al., 1991), coastal Florida (Fourqurean et al., 1993), and in the northern Red Sea, where it is co-limiting along with N (Mackey et al., 2009, 2011). Additionally, in regions where $\mathrm{P}$ does not limit primary productivity directly, DIP availability may still influence the physiological status of various phytoplankton species in different ways. For example, in upwelling regions along the Oregon coast, the $\mathrm{P}$ status of diatoms is more tightly controlled by DIP availability than it is for dinoflagellates (Dyhrman and Ruttenberg, 2006), and this could influence 
competition among these groups. In addition to primary producers, bacteria often experience P limitation in coastal waters (Sundareshwar et al., 2003).

Recent research has also highlighted the importance of dissolved organic P (DOP) as a nutrient source for phytoplankton. Many coastal phytoplankton species can grow on DOP as their sole source of P (Bjorkman and Karl, 1994), and DOP can be a source of $\mathrm{P}$ and $\mathrm{C}$ to heterotrophic bacteria (Kirchman et al., 2000). Several studies conducted in coastal upwelling zones along the California and Oregon coasts suggest that natural phytoplankton assemblages in these regions access the DOP pool (Dyhrman and Ruttenberg, 2006; Nicholson et al., 2006). Less is known about whether HAB species access DOP, or how their P status influences bloom dynamics. However, species-specific responses to various types of nutrient enrichment have been recorded (Anderson et al., 2002 and references therein), suggesting that $\mathrm{P}$ requirements of $\mathrm{HAB}$ species are also likely to be diverse. Understanding the role of DOP for phytoplankton nutrition in coastal upwelling regions is particularly intriguing given the typically large inventory of DOP relative to DIP in these regions, and the increasing supply of anthropogenic $\mathrm{N}$ to coastal regions that would tend to drive these systems toward P limitation and favor the ability of phytoplankton to access $\mathrm{P}$ bound in organic matter (Sylvan et al., 2006; Kudela et al., 2008).

Phosphorus in the DOP pool is made accessible to phytoplankton and other microbes via enzyme-mediated hydrolysis reactions that liberate orthophosphate from organic molecules. The enzyme alkaline phosphatase (AP) is one such enzyme that hydrolyzes phosphomonoester bonds, generating a free phosphate group, and an alcohol as products. In many organisms AP is synthesized in response to low ambient DIP levels, a characteristic that has led to its use as an indicator of DIP limitation in microbial communities (Dyhrman and Palenik, 1999). Different approaches have been used to quantify AP activity in environmental samples, and the techniques generally fall into one of two categories. The first are bulk community assays using phosphomonoester substrates (e.g., p-nitrophenyl phosphate and 4methylumbelliferylphosphate) that form soluble hydrolysis products in the presence of AP. These assays allow relatively rapid, high throughput quantitative analysis of samples, but are unable to distinguish which species in a mixed microbial assemblage contribute AP activity. This complicates studies on nutrient limitation of primary production, since the AP activity of phytoplankton cannot be distinguished from that of non-photosynthetic microbes. Measuring the AP activity of specific size-fractionated classes provides a greater amount of taxonomic resolution, but cannot distinguish between the AP activities of different species within the same size class, and may be prone to error in systems where bacteria form aggregates or coalesce on larger organic particles (Nicholson et al., 2006).

The second category of AP activity assays involve the direct labeling of cells at the location of the AP enzyme. These include staining with azo dyes (Barka, 1960), probing with antibodies (Dyhrman and Palenik, 2001), and precipitating lead phosphate (Mayahara et al., 1967). More recently, enzyme-labeled fluorescence (ELF) has been used to label phytoplankton cells with a fluorescent precipitate following hydrolysis of the non-fluorescent substrate molecule at the site of the AP enzyme (Dyhrman and Palenik, 1999; Nicholson et al., 2006; Mackey et al., 2007). Unlike bulk AP activity assays that provide quantitative measurement of AP hydrolysis rates, these cell-specific assays are qualitative, measuring the frequency of AP expression among a group of cells. Direct labeling assays are therefore useful when determination of taxon-specific AP activity is desired (such as by comparing the labeling of different species across a mixed assemblage), or when the degree of phosphate limitation within a given species is of interest (such as by comparing the frequency of labeled and non-labeled individuals of the same species).

This study uses ELF labeling to identify AP activity in microbial communities from Monterey Bay, California following an upwelling event that gave rise to a red tide. The red tide incubator (RTI) is a persistent feature of northeastern Monterey Bay, where dense dinoflagellate populations frequently develop (Ryan et al., 2008), and from which blooms may spread rapidly throughout the bay and along the adjacent coast (Ryan et al., 2009). Dinoflagellate species that incubate in the RTI may cause harmful effects through multiple mechanisms, including production of toxins and surfactants (Ryan et al., 2008; Jessup et al., 2009; Kudela et al., 2010). The first documented case of seabird mortality caused by a surfactant-producing red tide occurred in the RTI (Jessup et al., 2009). The cost of such HABs in the United States is estimated to be $\$ 82$ million per year (Hoagland and Scatasta, 2006), providing a clear economic incentive to understand $\mathrm{HAB}$ dynamics such that mitigation strategies can be developed.

In this study, we use water chemistry data collected during three sampling events to understand the fate of upwelled $\mathrm{P}$ and its partitioning between inorganic and organic reservoirs. Observations of phytoplankton relative abundance and AP activity are used to understand how $\mathrm{P}$ availability affects community composition and contributes to $\mathrm{HAB}$ formation in this dynamic environment. This study increases our understanding of the cell-specific $\mathrm{P}$ status of red tide phytoplankton during bloom formation by examining of a broad range of species and measuring their responses to $\mathrm{P}$ dynamics following upwelling.

\section{MATERIALS AND METHODS SAMPLING}

Samples were collected from an along shore transect located within the RTI (Ryan et al., 2008, 2011) region of Monterey Bay during three sampling events on 7, 14, and 21 of October 2008 that spanned an upwelling event. We refer to these dates as "preupwelling," "upwelling," and "relaxation" respectively; however, these terms refer to the arrival of upwelled water to our sampling sites rather than to the wind conditions (which can also be used to identify upwelling). The "pre-upwelling" sampling on 7 October occurred during early arrival of upwelling favorable winds, but prior to the arrival of recently upwelled waters in the Bay (Ryan et al., 2011). Oceanographic conditions on that date evidently reflected the lack of strong upwelling favorable winds in the week preceding sampling. The "upwelling" sampling on 14 October occurred when the sea surface temperature response to the strong upwelling winds (October 7-12) was at a maximum. Accordingly, oceanographic conditions define strong upwelling response on this date, even though winds on this sampling day were 
not as strong. The "relaxation" sampling on 21 October occurred when winds were moderate, but the oceanographic conditions still reflected relaxation of the preceding upwelling event.

The sampling transect stretched between the outlets of Elkhorn Slough and Pajaro Creek, extending northwest toward the San Lorenzo River outlet with the following six stations (Figure 1): St1 (121.8018W, 36.8161N), St2 (121.8218W, 36.8454N), St3 $(121.8437 \mathrm{~W}, 36.8834 \mathrm{~N}), \quad$ St4 $(121.8674 \mathrm{~W}, 36.9120 \mathrm{~N}), \quad$ St5 (121.8938W, 36.9406N), and St6 (121.9311W, 36.9571N). Temperature and salinity were measured continuously at $2 \mathrm{~m}$ via an underway system during each cruise. Temperature and chlorophyll fluorescence were also monitored continuously at two moorings located at the northern and southern ends of the RTI (Figure 1) throughout October as described by Ryan et al. (2011).

\section{WATER CHEMISTRY}

Sample water was syringe filtered $(0.45 \mu \mathrm{m})$ into acid washed, sample rinsed plastic bottles and frozen until analysis. Seawater concentrations of soluble reactive phosphorus (SRP), nitrate $\left(\mathrm{NO}_{3}\right.$, including trace amounts of nitrite), and silicate were analyzed using colorimetric methods described by Hansen and Koroleff (1999) modified for a flow injection autoanalyzer (FIA, Lachat Instruments Model QuickChem 8000). The detection limits were $0.03 \mu \mathrm{mol} \mathrm{SRP} \mathrm{L}{ }^{-1}, 0.04 \mu \mathrm{mol} \mathrm{NO}_{3}^{-} \mathrm{L}^{-1}$, and $0.04 \mu \mathrm{mol}$ silicate $\mathrm{L}^{-1}$. SRP is operationally defined and includes any $\mathrm{P}$ compounds that can be detected using the molybdenum blue colorimetric

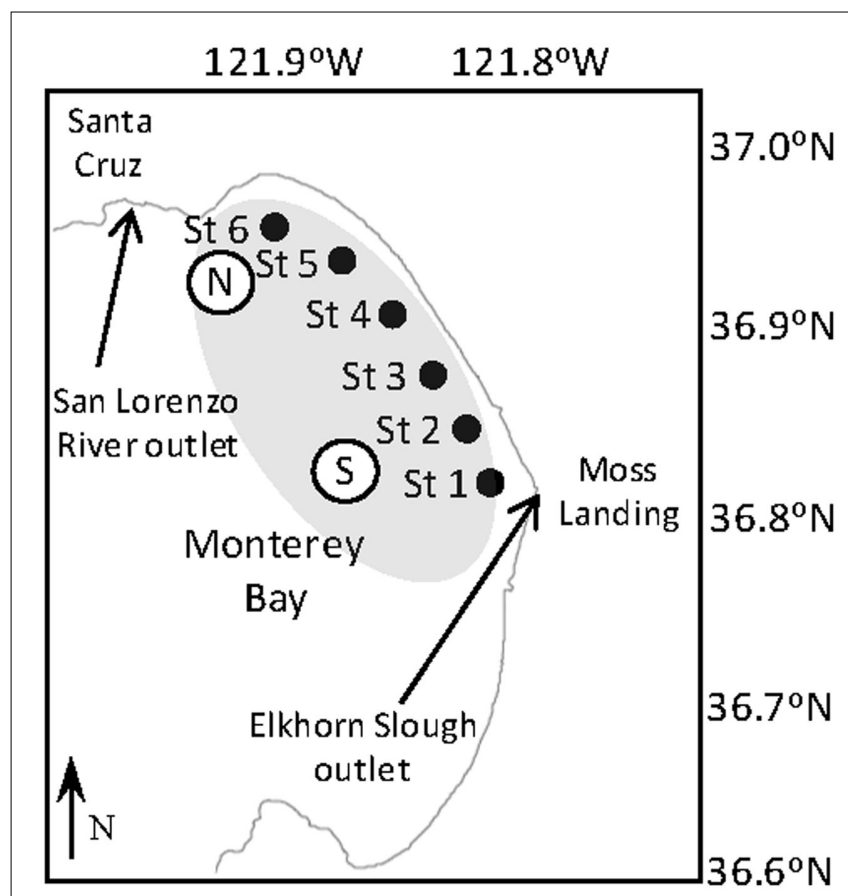

FIGURE 1 | Map of Monterey Bay showing the location of the six sampling stations (closed circles, labeled Station 1-6) within the red tide incubator. The open circle labeled " $N$ " denotes the location of the northern RTI mooring. The open circle labeled "S" denotes the location of the southern mooring, which is the location where water for the incubation experiment was collected. Shaded region shows approximate location of the RTI. assay. In coastal waters SRP provides a robust approximation of DIP (Monaghan and Ruttenberg, 1999), although it can include other forms of P. For simplicity we refer to SRP as DIP throughout the text.

Total dissolved $\mathrm{P}$ and $\mathrm{N}$ samples were analyzed following persulfate digestion as described in D'Elia et al. (1977) and Valderrama (1981). The precision for these measurements was $4 \%$ based on duplicate measurements from a single sample bottle. The detection limit was $0.2 \mu \mathrm{mol} \mathrm{L}^{-1}$ for total $\mathrm{P}$ and $1.5 \mu \mathrm{mol} \mathrm{L}^{-1}$ for total N. DOP was calculated as the difference of total dissolved $\mathrm{P}$ and SRP. Dissolved organic $\mathrm{N}$ was calculated as the difference between total dissolved $\mathrm{N}$ and $\mathrm{NO}_{3}^{-}$, and may include a small $(<5 \%)$ contribution from ammonium.

Samples for DOC analysis were filtered through a sterile $0.2-\mu \mathrm{m}$ filter and collected into acid washed and combusted borosilicate glass scintillation vials with teflon lined screw caps. Samples were acidified with $\mathrm{HCl}$ to $\mathrm{pH}<2$ and purged to remove inorganic (and purgeable organic) carbon, stored cold $\left(4^{\circ} \mathrm{C}\right.$ ) in the dark until analysis. Samples were analyzed using a Shimadzu TOC analyzer (EPA method 415.1). The detection limit was $1 \mu \mathrm{mol} \mathrm{L}^{-1}$.

\section{ELF PHOSPHATASE ASSAY}

The endogenous phosphatase detection kit (Molecular Probes E 6601) was used to detect cell-specific phosphatase activity. The ELF 97 phosphatase substrate, ELF-P, [2-(5'-ochloro-2'phosphoryloxyphenol)-6-chloro-4- $(3 \mathrm{H})$-quinazolinone] is a soluble molecule that forms an insoluble alcohol precipitate following cleavage of the phosphate group by the AP enzyme. One liter seawater samples were filtered at low pressure unto $0.45 \mu \mathrm{m}$ filters, gently eluted with $800 \mu \mathrm{L} 70 \%$ ethanol, and stored at $0^{\circ} \mathrm{C}$ until analysis. Dimethyl sulfoxide (DMSO) was added to a final concentration of $10 \%$ to enhance cell penetration by the ELF-P substrate and improve labeling clarity (Lomas et al., 2004). Samples were incubated in the DMSO for $30 \mathrm{~min}$ in the dark, centrifuged ( $5 \mathrm{~min}$, $5000 \mathrm{rpm}$ ), and the supernatant discarded. The ELF-P substrate was diluted 1:20 into the provided buffer. The cell pellets were resuspended in $100 \mu \mathrm{L}$ of this mixture and incubated in the dark at $4^{\circ} \mathrm{C}$ for $1 \mathrm{~h}$. To stop the reaction, the cells were rinsed with $100 \mu \mathrm{L}$ sterile artificial seawater, centrifuged ( $5 \mathrm{~min}, 5000 \mathrm{rpm}$ ), and the supernatant discarded. Cell pellets were resuspended in $10 \mu \mathrm{L}$ sterile artificial seawater and stored in the dark at $4^{\circ} \mathrm{C}$. Cell counts and scoring of fluorescent labeling was conducted using a Leitz DMRB microscope equipped with a DAPI filter set and UV excitation $(\sim 345 \mathrm{~nm})$, and photographed with a Leica DC500 camera. Cells were scored as being positive for AP activity if any portion of the cell was labeled with the ELF precipitate. Phytoplankton taxa were identified following Tomas (1997).

\section{NUTRIENT ADDITION BIOASSAY}

An incubation experiment was conducted with water collected near the southern edge of the RTI region (Figure 1) beginning October 4, 2009, as described in Mackey et al. (2010). Treatments included control (no addition), as well as nutrient additions with final concentrations of either $1.5 \mu \mathrm{mol} \mathrm{L}^{-1} \mathrm{NaH}_{2} \mathrm{PO}_{4}$ as a source of DIP, $1.5 \mu \mathrm{mol} \mathrm{L}^{-1}$ phytic acid as a source of DOP (equivalent to $9 \mu \mathrm{mol} \mathrm{P} \mathrm{L}{ }^{-1}$ ), or $25 \mu \mathrm{mol} \mathrm{L}^{-1} \mathrm{NaNO}_{3}$ as a source of $\mathrm{NO}_{3}^{-}$. These concentrations are equivalent to levels that are routinely measured 
in Monterey Bay following large upwelling events (Pennington and Chavez, 2000). Treatments were conducted in triplicate using acid washed, seawater rinsed polycarbonate bottles. Bottles were incubated for $30 \mathrm{~h}$ in a tank with circulating seawater to maintain ambient temperature, and were shaded with neutral density screen that provided 50\% light attenuation. Chl $a$ was measured fluorometrically as described previously (Mackey et al., 2010).

\section{RESULTS}

\section{WATER CHEMISTRY}

Water chemistry was monitored during three sampling events that occurred immediately before, during, and 1 week after an upwelling event in October 2008. Upwelling brought colder, more saline water to the surface (Figures $\mathbf{2}$ and $\mathbf{3}$ ), and was characterized by high inorganic nutrient and DOC concentrations, and low organic nutrient concentrations (Figure 3). During relaxation of upwelling, inorganic nutrient concentrations declined, while organic nutrient levels increased. DIP concentrations increased more than 10-fold during upwelling, increasing from 0.05 to $0.54 \mu \mathrm{mol} \mathrm{L}^{-1}$. The DIP concentration decreased to $0.26 \mu \mathrm{mol} \mathrm{L}^{-1}$ over the following week as upwelling relaxed (Figure 3). $\mathrm{NO}_{3}^{-}$followed a similar pattern, increasing 25-fold from 0.05 to $1.76 \mu \mathrm{mol} \mathrm{L}^{-1}$ during upwelling, and then decreasing to at or below detection limit $\left(0.04 \mu \mathrm{mol} \mathrm{L}^{-1}\right)$ during relaxation. [We note that the $\mathrm{NO}_{3}^{-}$enrichment we observed in the RTI following upwelling was low compared to other nearby locations; for example, $\mathrm{NO}_{3}^{-}$levels as high as $15 \mu \mathrm{mol} \mathrm{L}^{-1}$ was observed in the center of Monterey Bay during this study period (Ryan et al., 2011)]. Silicate increased sharply from 1.5 to $11.0 \mu \mathrm{mol} \mathrm{L}^{-1}$ during upwelling, but was only drawn down slightly during relaxation, reaching $10.1 \mu \mathrm{mol} \mathrm{L}^{-1}$ by October 21 . In contrast to the inorganic nutrients, DOP and DON both decreased slightly during upwelling but doubled as upwelling relaxed, reaching $0.8 \mu \mathrm{mol}$ and $28 \mu \mathrm{mol} \mathrm{L}^{-1}$ respectively (Figure 3). DOC concentrations followed a pattern more similar to the inorganic nutrients, increasing from 0.3 to $1.7 \mu \mathrm{mol} \mathrm{L}^{-1}$ during upwelling, and then declining during relaxation (Figure 3). The ratio of DON:DOP concentrations was relatively consistent before, during, and after the upwelling event (Figure 4), while the ratio of $\mathrm{NO}_{3}^{-}$: DIP concentrations only changed during the period of upwelling. However, the $\mathrm{NO}_{3}^{-}$: DIP ratios were always well below the Redfield ratio of $16: 1$ that phytoplankton typically require for growth (Figure 4).

\section{BLOOM DEVELOPMENT AND COMMUNITY COMPOSITION}

An upwelling event introduced cold, nutrient rich water into the RTI region between October 10-15 (Figures 2 and 3). This upwelling gave rise to a phytoplankton bloom (i.e., a rapid increase in photosynthetic biomass), where Chl $a$ levels within the RTI increased from $\sim 5 \mu \mathrm{g} \mathrm{L}^{-1}$ before upwelling to nearly $20 \mu \mathrm{g} \mathrm{L}^{-1}$ following upwelling (Figure 2). Here we report the relative abundances of diatoms and dinoflagellates during that bloom (i.e., the fraction of cells belonging to either group out of the total number of diatoms and dinoflagellates cells counted). Diatoms and dinoflagellates were the major types of phytoplankton in our samples, together comprising $>99 \%$ of cells in the size class we counted $(>2 \mu \mathrm{m})$. These cells were present at concentrations on the order of 100 s to 1,000 s of cells per liter based on the concentration factor used for samples during the ELF assay (e.g., $1 \mathrm{~L}$ seawater concentrated to $10 \mu \mathrm{L}$ ). We note that an abundant and diverse picoplankton community (cells $<2 \mu \mathrm{m}$ ) of Synechococcus and picoeukaryotes also exists in the waters of coastal California (Toledo and Palenik, 1997; Worden, 2006); however, enumeration of these cells (which are not known to form red tides in Monterey Bay) was outside the scope of the present study. Excluding picoplankton, the overall Shannon-Weaver diversity index $(H)$ for phytoplankton in the RTI during our study was 2.82 . The highest diversity and evenness of phytoplankton was observed at station $4\left(H_{4}=2.82\right)$. Stations $1,2,3$, and 5 had slightly lower diversity indices $(2.61,2.65,2.68$, and 2.57 respectively), and the lowest diversity index was observed at station 6 on the edge of the RTI furthest from the outlet of Elkhorn Slough $\left(H_{6}=2.48\right.$, Figure 1).

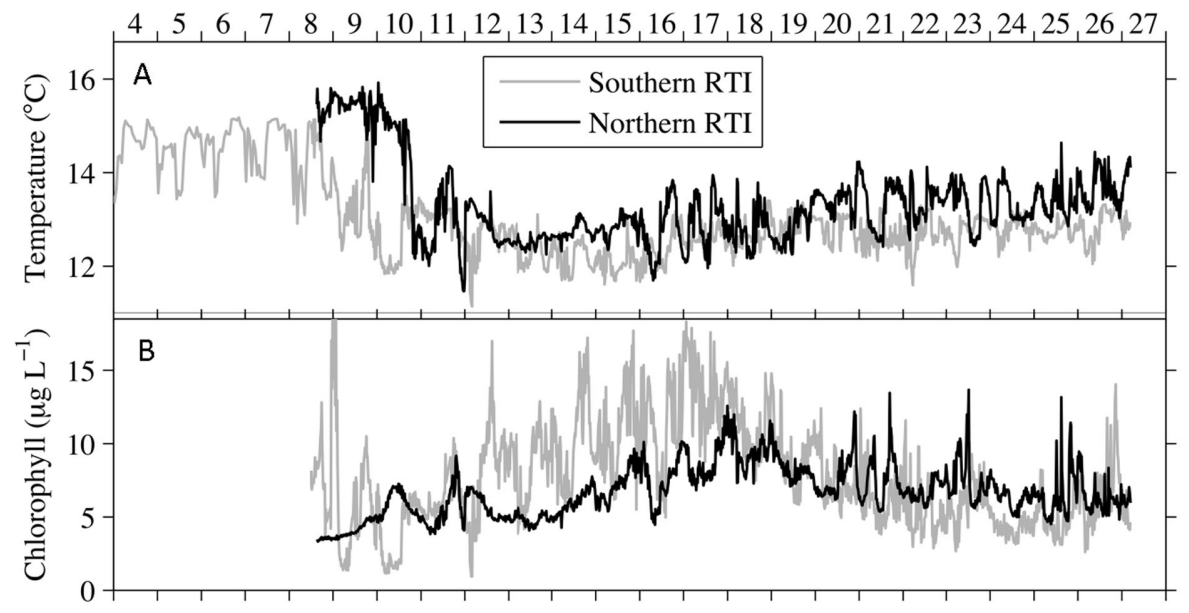

FIGURE 2 |Time series for the northern and southern RTI showing (A) the intrusion of cold upwelled water, and (B) increased chlorophyll indicative of the phytoplankton bloom that occurred in response to upwelling. Data are reproduced from Ryan et al. (2011). 


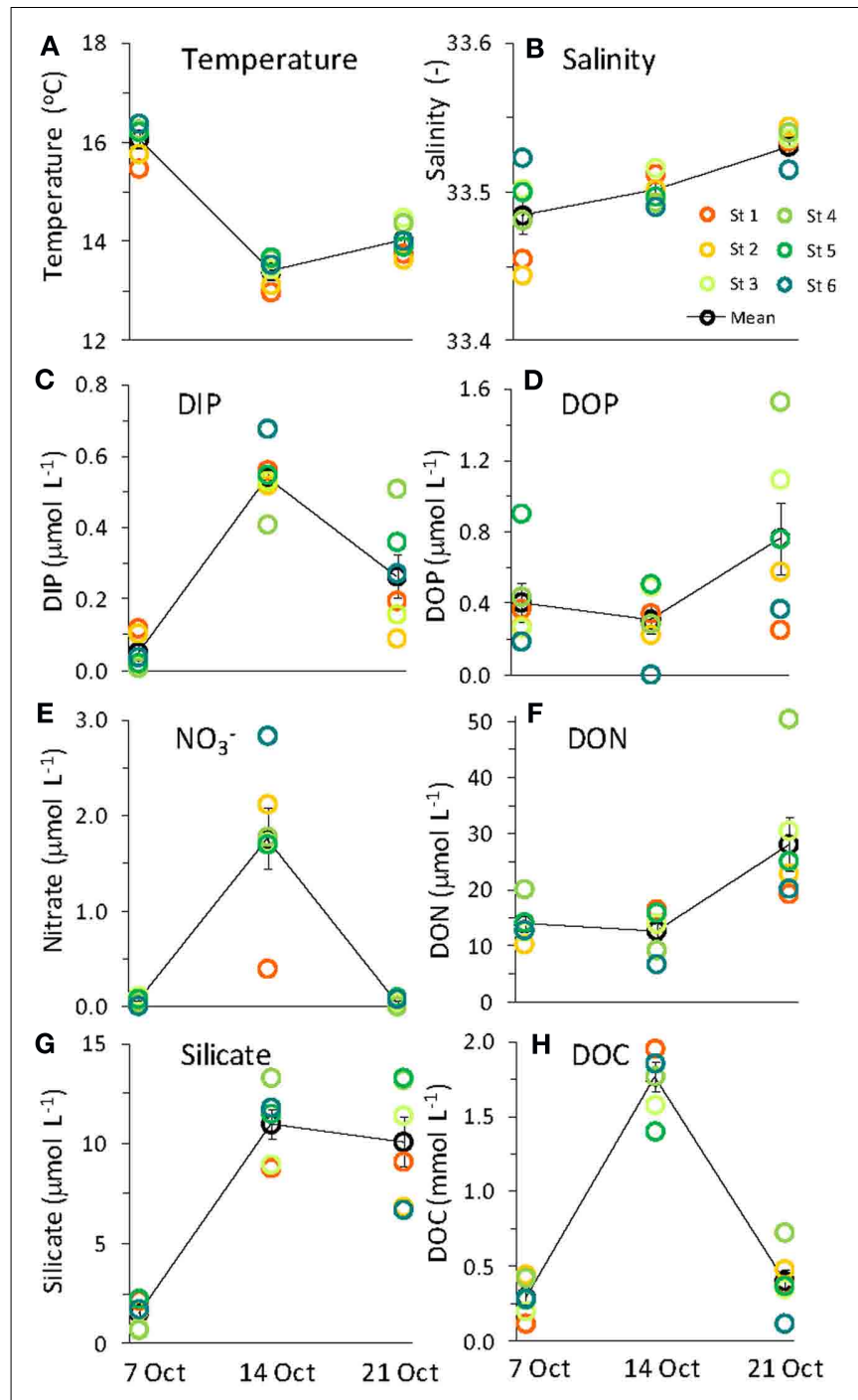

FIGURE 3 |Water chemistry before (October 7) and during (October 14) upwelling, and during upwelling relaxation (October 21). Legend for all panels as in (B). Error bars show SE.

The phytoplankton population initially was a complex assemblage composed of roughly equal densities of diatoms and dinoflagellates, but transitioned toward a higher relative abundance of dinoflagellates following upwelling (Figure 5). Diatoms initially represented $47 \%$ of cells counted before upwelling occurred. Following upwelling and relaxation, the relative abundance of diatoms decreased to $8-25 \%$ in stations $1-5$, but remained high at station 6 (54\%; Figure 5). The diatom community was composed of a mixture of centric diatoms, pennate diatoms (e.g., Pseudo-nitzschia, Rhizosolenia), and chain-forming diatoms (e.g., Chaetoceros, Thalassiosira, Thalassionema; Figure 6). The highest diatom diversity was observed at stations 5 and 6 . These stations were located on the edge of the RTI region, furthest from the open ocean and the upwelling front.

Dinoflagellate relative abundance was $\sim 53 \%$ before upwelling occurred, but increased dramatically to up to $92 \%$ in the weeks

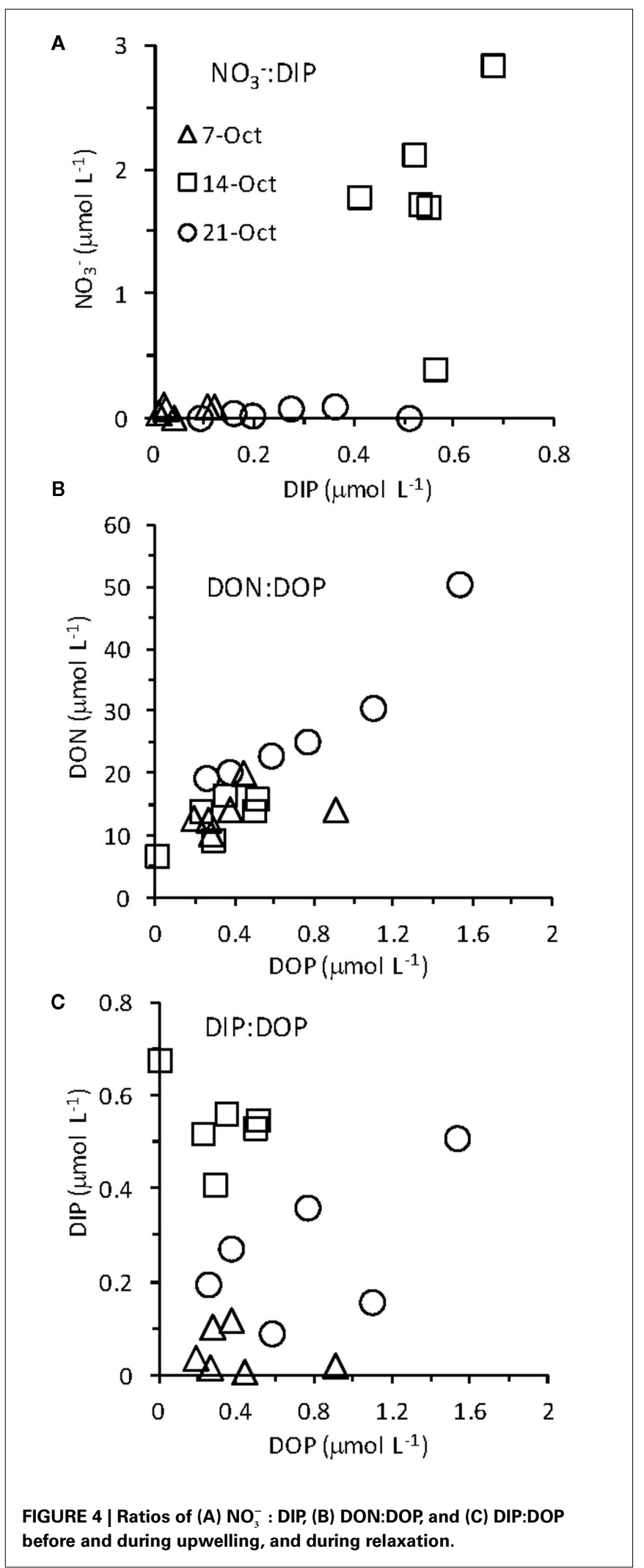

following upwelling in stations 1-4 (Figures 5 and 7). Like the diatoms, the dinoflagellate relative abundance did not change 


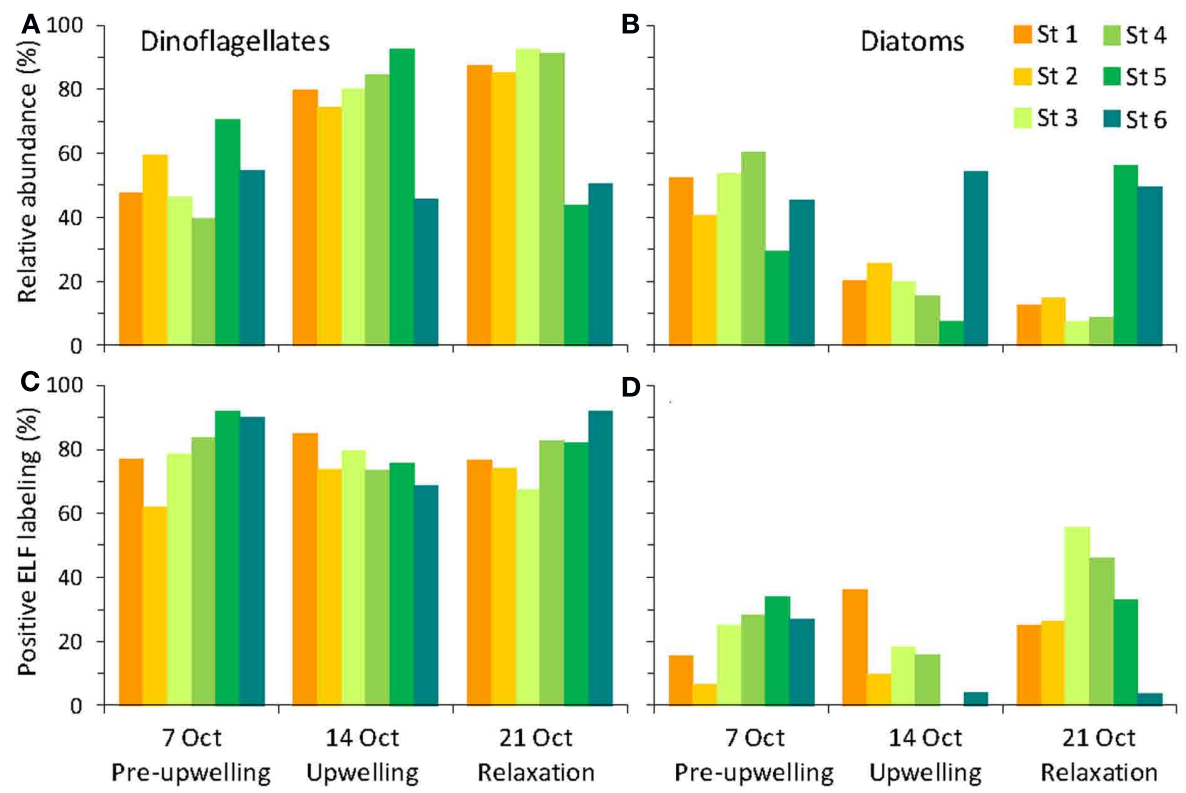

FIGURE 5 | Relative abundance (A, B) and percent ELF labeling (C,D) of dinoflagellates (A,C) and diatoms (B,D).

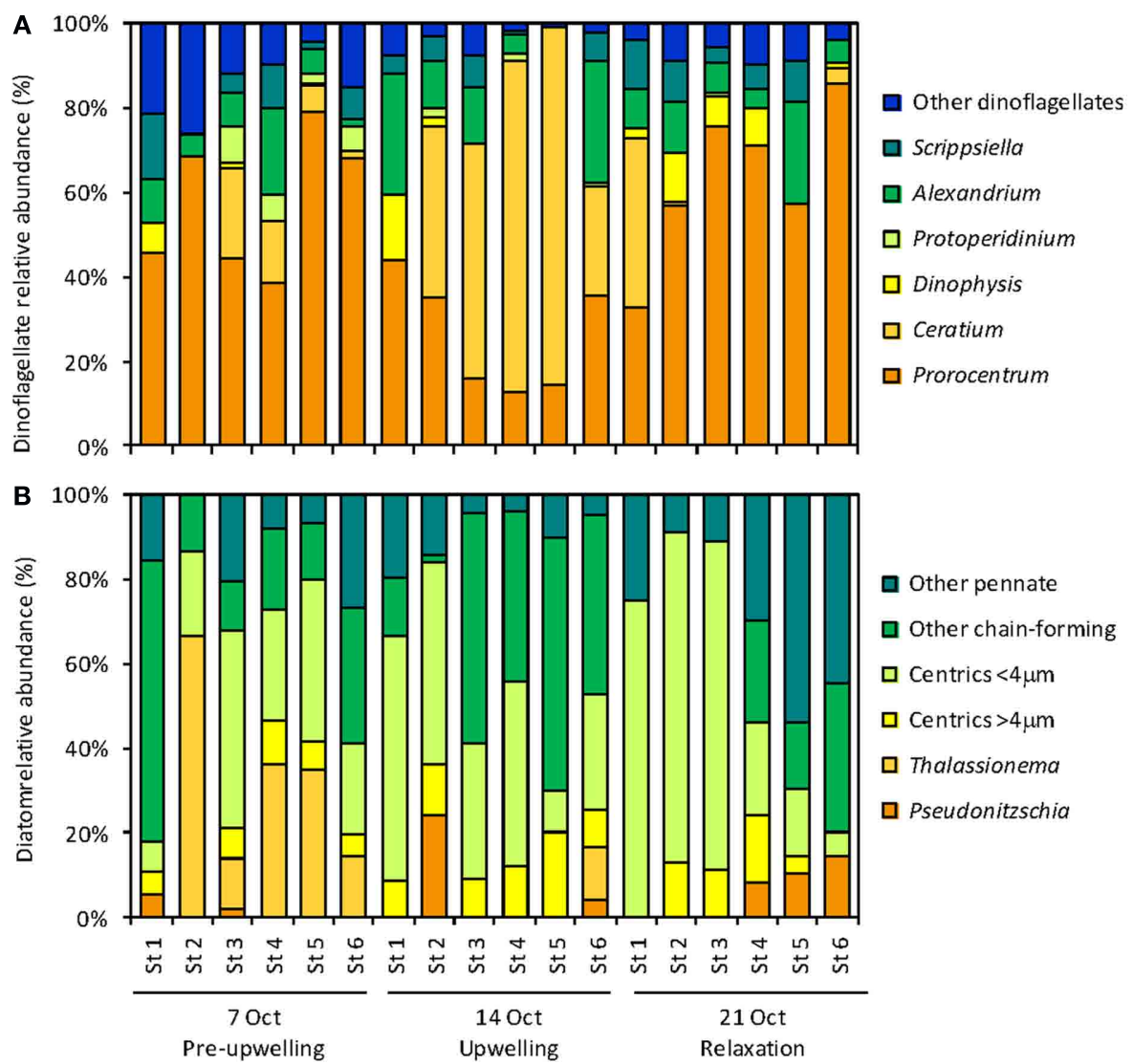

FIGURE 6 | Relative abundances of (A) dinoflagellate genera, and (B) diatom taxa observed at the six stations during the sampling period. 
appreciably at station 6 during the sampling period (50\%; Figure 5). The dinoflagellate community was taxonomically diverse and showed a high degree of spatial heterogeneity among genera (Figure 6). Prorocentrum was present at all stations in all weeks of sampling and comprised between 13 and $67 \%$ of dinoflagellate cells (Figure 6). Several species of Prorocentrum spp. were identified, including $P$. micans, $P$. minimum, $P$. gracile, $P$. dentatum, $P$. sigmoides, and $P$. triestinum (Figure 8). Of these, $P$. micans was generally the most abundant and most ubiquitous, followed by $P$. minimum. The highest relative abundances of Prorocentrum spp. occurred in week 3 at stations 3 and 4 .
A large, localized bloom of Ceratium spp. was centered in stations 4 and 5 in week 2, where Ceratium spp. cells comprised over $50 \%$ of the dinoflagellates counted at those stations (Figure 6). Species included Ceratium balechii, C. furca, and rarely C. lineatum. C. balechii was approximately twofold more abundant than C. furca in these bloom samples. The morphology of C. furca cells was remarkably conserved, whereas greater variability occurred in the size and shape of $C$. balechii cells (Figure 9). We identified C. balechii based on its morphological similarity to previously described specimens (Meave del Castillo et al., 2003; HernándezBecerril and Alonso-Rodríguez, 2004; Gomez et al., 2008; Pitcher

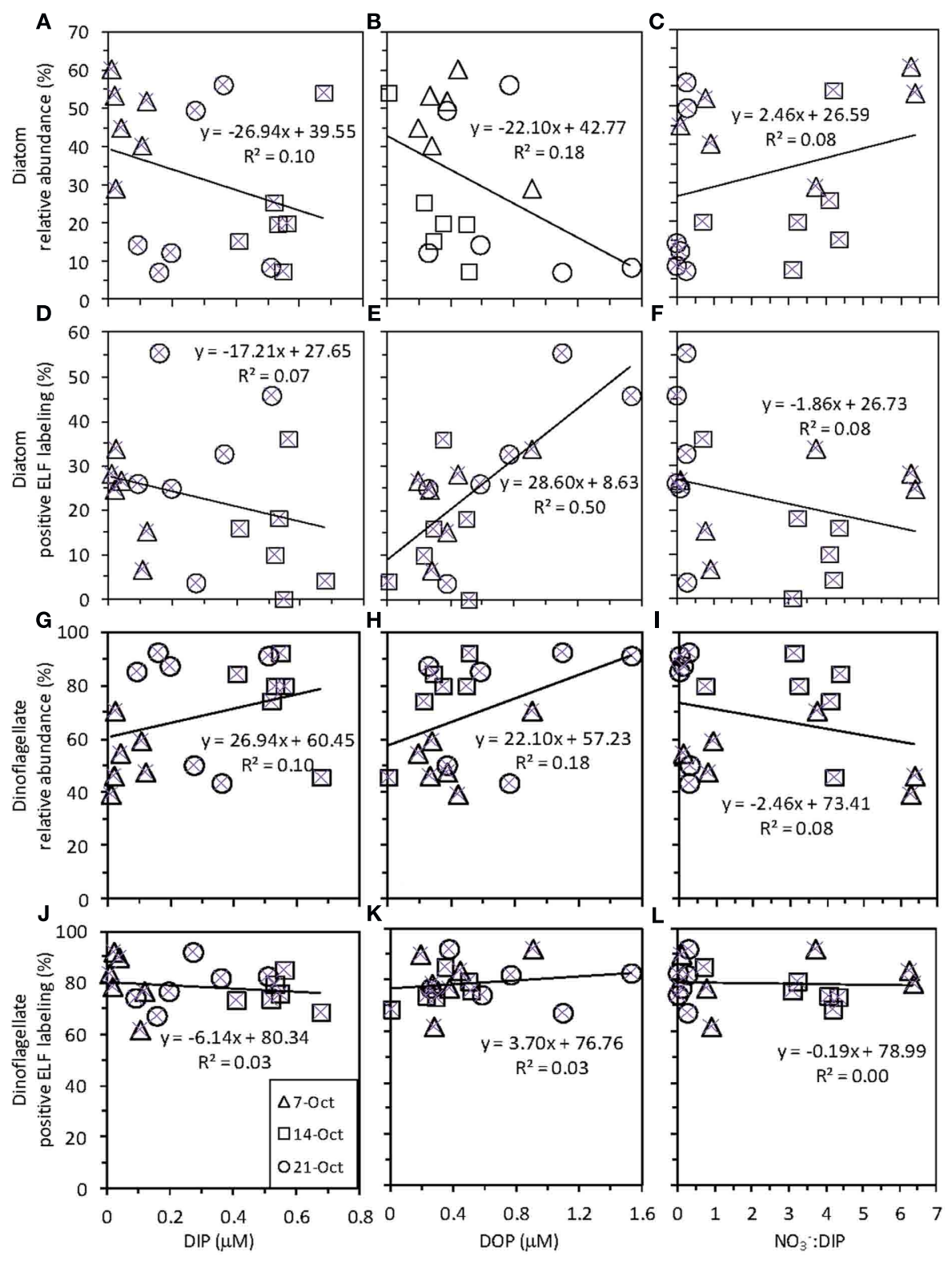

FIGURE 7 | Correlations between seawater nutrient (DIP, DOP, and $\mathrm{NO}_{3}^{-}$: DIP) and phytoplankton data (diatom and dinoflagellate relative abundance and ELF labeling). Each panel shows data for all six stations on each of three sampling dates [legend as in (J) for all panels]. Each panel shows the best fit line and correlation coefficient for all data points together. 

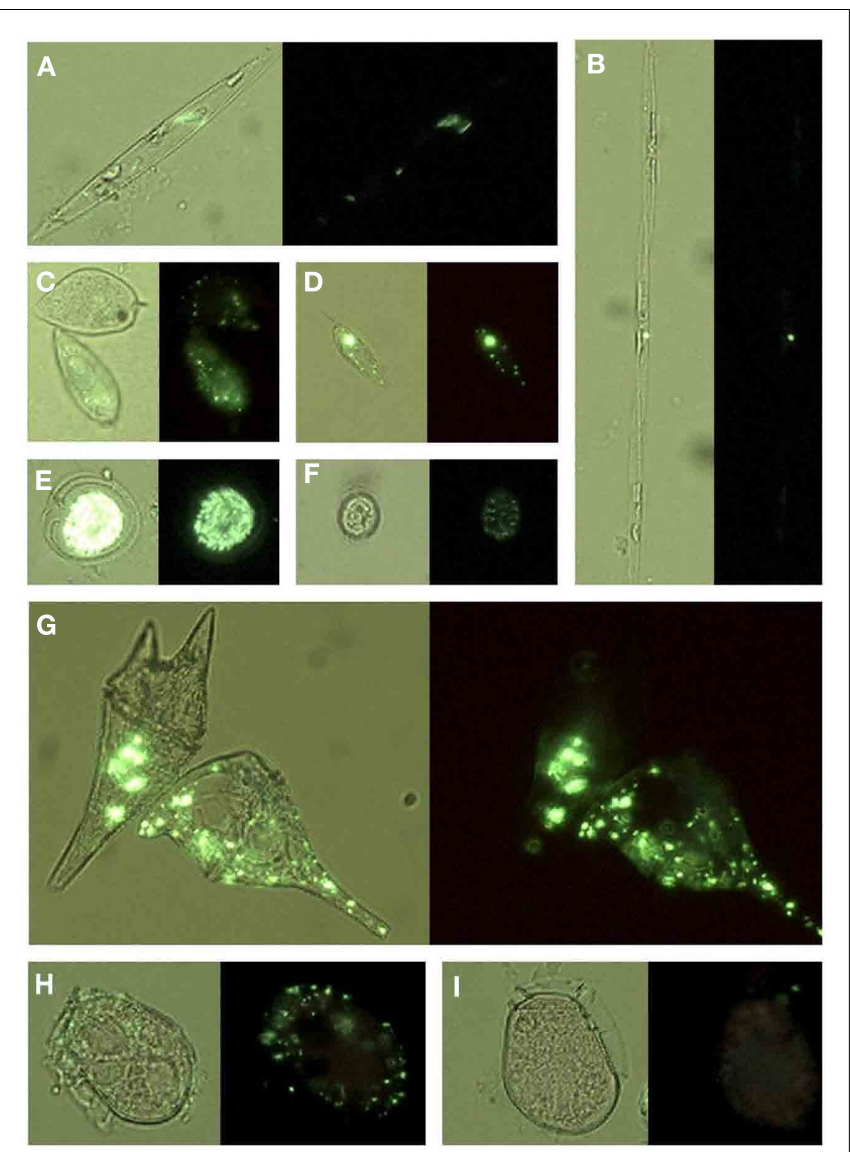

FIGURE 8 | Micrographs showing ELF labeled phytoplankton: (A) Rhizosolenia, (B) Pseudo-nitzschia, (C) Prorocentrum micans (top) and $P$ gracile (bottom), (D) P. rostratum, (E) Prorocentrum sp, (F) $P$. minimum, (G) Ceratium furca (left) and $C$. balechii (right), (H) Dinophysis fortii with attached bacteria, (I) Dinophysis fortii. Cells are shown under UV illumination with visible light on (light background) and off (dark background).

and Probyn, 2011). This species is characterized by considerable diversity, is often confused with other species (e.g., C. dens, $C$. divaricatum, C. tripos), and has been the subject of taxonomic debate. The morphological form of C. balechii from the RTI region of Monterey Bay differs from other examples in the literature in that it has highly reduced antapical horns, giving it a rounded appearance (Figures 9C-H). The only example of this rounded morphotype in the literature was a single specimen reported in the open southeast Pacific Ocean (Gomez et al., 2008). In contrast, specimens from the Mexican tropical Pacific Ocean (Meave del Castillo et al., 2003; Hernández-Becerril and Alonso-Rodríguez, 2004) and the southern Benguela upwelling region of the Atlantic Ocean (Pitcher and Probyn, 2011) typically retain some portion of their antapical horns. All specimens observed in our samples had the rounded phenotype, although subtle morphological differences were apparent. For example, some individuals retained the pentagonal cell shape characteristic of the species (Figures 9C-E), whereas the rounding obscured this shape in others, giving more of a circular cell shape (Figure 9F). This morphotype of C. balechii
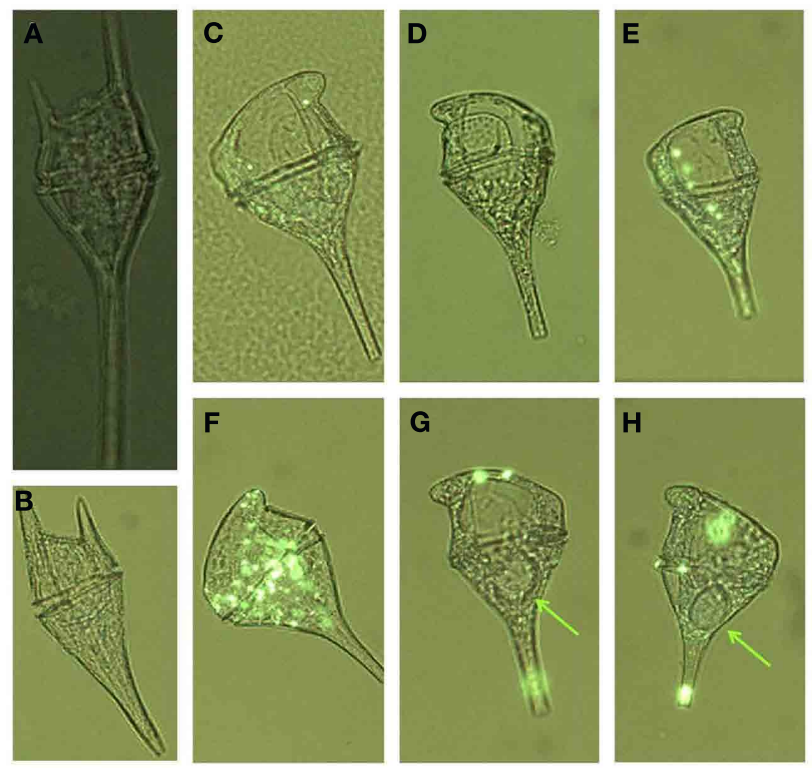

FIGURE 9 | Micrographs of different forms of Ceratium cells encountered from the red tide incubator region of Monterey Bay showing (A) C. lineatum, (B) C. furca, (C-H) different morphologies of C. balechii. Green arrows in $\mathbf{( G , H )}$ indicate the location of feeding vacuoles that were observed in some individuals. Cells are shown under UV illumination with visible light on, and ELF labeling is visible in some cells as bright green regions.

has been observed routinely in Monterey Bay (R. Kudela, personal communication), suggesting that it might be endemic to the region and may represent a distinct taxonomic group.

A smaller localized bloom of Scrippsiella, Alexandrium, and Dinophysis occurred at stations 1 and 2 during weeks 2 and 3, where together they comprised $\sim 15-25 \%$ of cells (Figure 6). While Scrippsiella and Alexandrium were also observed at all other sites throughout the sampling period, Dinophysis spp. was rarely observed at stations 5 and 6. Species of Dinophysis spp. included D. acuminata and D. fortii. Other rarer types of dinoflagellates included Oxyphysis, Oxytoxum, Phalachroma, and several species of Protoperidinium.

\section{ALKALINE PHOSPHATASE ACTIVITY}

Alkaline phosphatase (AP) activity was assessed via the ELF assay. Throughout the sampling period, diatom AP activity showed a higher degree of spatial variability and sensitivity to DIP and DOP availability compared to dinoflagellates (Figures 5 and 7). Before upwelling occurred, an average of $22 \%$ of diatoms showed strong ELF labeling (range, 7-34\%), and the degree of labeling increased with distance from the outlet of Elkhorn Slough (Figure 5). During upwelling when DIP was high, the amount of ELF labeling decreased to between 0 and $18 \%$ for all stations except station $1(36 \%)$. During relaxation, the fraction of labeled diatom cells reached its highest value of 32\% (range, 26-56\%), except for station 6 , where diatoms retained very low labeling $(\sim 4 \%)$. Interestingly, a stronger correlation existed between diatom ELF labeling and DOP $\left(R^{2}=0.50\right)$ than between diatom ELF labeling 
and DIP $\left(R^{2}=0.07\right)$. There was no consistent trend in labeling within diatom species, and most groups included both labeled and non-labeled individuals.

In contrast to diatoms, the dinoflagellate population had higher proportions of ELF labeled cells (62-92\%, average 79\%, Figure 5) and the extent of labeling was less sensitive to ambient $\mathrm{NO}_{3}^{-}$: DIP ratio, or to DIP or DOP (Figure 7).

The combined ELF labeling of cells from all Prorocentrum species was relatively uniform on the three sampling dates (average of all six stations for each date was consistently $\sim 80 \%$ ). On average, $82 \%$ of Prorocentrum micans cells exhibited ELF labeling (range, 62-100\%) throughout the sampling period, showing little temporal variability. The ELF labeling of $P$. minimum cells was more responsive to DIP availability, declining from 72 to $53 \%$ during upwelling when DIP levels were highest. By week three, the extent of labeling in P. minimum returned to pre-upwelling levels, reaching $78 \%$. For P. minimum the extent of ELF labeling varied widely by station (range, $0-100 \%$ ), although this variability could be due in part to low abundances of $P$. minimum in some samples. Other Prorocentrum species, such as the less abundant $P$. gracile and $P$. triestinum, showed strong, positive ELF labeling in nearly all cells counted (Figure 8).

Ceratium balechii had consistently high ELF labeling of $>95 \%$ in most of the samples where it occurred. C. furca labeling was more variable, and ranged from 47 to $100 \%$ in different samples. On average $\sim 70 \%$ of Dinophysis acuminata cells were ELF labeled, whereas $<10 \%$ of $D$. fortii cells were labeled. However, a number of $D$. fortii cells had bacterial cells on their surfaces that were ELF labeled. In general both species were more highly labeled where the cells were most abundant; i.e., stations 1 and 2 in weeks 2 and 3 as described above (Figure 6). On average, 89\% of Scrippsiella cells and 74\% of Alexandrium cells exhibited positive ELF labeling.

Enzyme-labeled fluorescence labeling was also observed in bacteria affixed to the surfaces of intact cells, as well as associated with lysed cell debris and aggregates of particulate organic material (Figure 10).

\section{NUTRIENT ADDITION BIOASSAY}

An incubation experiment was conducted to gage the response of phytoplankton from the RTI region of Monterey Bay to availability of $\mathrm{NO}_{3}^{-}$, DIP, and DOP during non-upwelling (pre-bloom) conditions. The initial Chl a concentration was $26 \pm 6 \mu \mathrm{g} \mathrm{L}^{-1}$, and after $30 \mathrm{~h}$, Chl $a$ remained similar in the control $\left(25 \pm 3 \mu \mathrm{g} \mathrm{L}^{-1}\right)$. Chlorophyll increased significantly relative to the control in the $\mathrm{NO}_{3}^{-}\left(40 \pm 0.4 \mu \mathrm{g} \mathrm{L}^{-1}\right)$, DIP $\left(34 \pm 3 \mu \mathrm{gL}^{-1}\right)$, and DOP $\left(30 \pm 1 \mu \mathrm{gL}^{-1}\right)$, treatments ( $t$-tests, $p<0.05$; Figure 11$)$.

\section{DISCUSSION}

\section{P CYCLING AND PHYTOPLANKTON BLOOM DYNAMICS}

Monterey Bay is a dynamic, spatially heterogeneous region that is strongly influenced by wind-driven upwelling that varies seasonally in intensity and intermittency (Pennington and Chavez, 2000; Ryan et al., 2011). In this study we sought to understand the dynamics of $\mathrm{P}$ availability and cycling following an upwelling event that spurred growth of HAB phytoplankton in the RTI region of Monterey Bay.
Upwelling dramatically increased the concentration of DIP in surface waters in October 2008. DIP was then quickly consumed as upwelling relaxed and the phytoplankton bloom developed. The response of phytoplankton to the upwelling pulse was evidently variable over relatively small scales. In the middle to outer northern bay, toxigenic diatoms dominated the response to upwelling (Ryan et al., 2011). However, within the RTI closer to shore where we monitored $\mathrm{P}$ dynamics and phytoplankton, the bloom was characterized by a shift from a mixed diatom and dinoflagellate assemblage toward one dominated by dinoflagellates. As the inner shelf bloom progressed, DOP accumulated in surface waters, possibly suggesting that phytoplankton are a source of DOP through direct excretion or grazing, as proposed for the Oregon upwelling region (Ruttenberg and Dyhrman, 2005). The concurrent increase in DOP along with the decline of the diatom population could signal this effect in particular since diatom cells are more susceptible to fracture during grazing. This could result in DOP release through sloppy grazing (Dagg, 1974; Lampert, 1978) as has been suggested for DON in Monterey Bay (Bronk and Ward, 1999).

Like many coastal upwelling regions, phytoplankton productivity in Monterey Bay responds strongly to $\mathrm{NO}_{3}^{-}$availability over interannual cycles (Kudela and Chavez, 2000; Pennington and Chavez, 2000), and phytoplankton growth is stimulated by $\mathrm{NO}_{3}^{-}$in bottle incubation experiments (Kudela and Dugdale, 2000; Mackey et al., 2010). In this study, an incubation experiment with natural seawater collected from the RTI region conducted during non-upwelling (pre-bloom) conditions showed the strongest $\mathrm{Chl}$ $a$ increases following $\mathrm{NO}_{3}^{-}$additions, with smaller responses for DIP and DOP (Figure 11). N limitation was also indicated by the $\mathrm{NO}_{3}^{-}$: DIP ratios in the seawater, which were consistently below the Redfield ratio of 16:1 typically required for phytoplankton growth (Redfield et al., 1963; Figures 4 and 7).

While $\mathrm{N}$ availability appears to be the primary factor controlling phytoplankton abundance in Monterey Bay, several lines of evidence suggest that $\mathrm{P}$ availability also regulates the growth and physiological status of cells. First, the moderate increase in phytoplankton growth relative to the untreated control in the incubation experiment suggests that some components of the RTI phytoplankton community are indeed $\mathrm{P}$ limited. Second, the high yet variable amount of AP activity revealed through ELF labeling suggests that different species have diverse strategies for coping with $\mathrm{P}$ limitation (e.g., inducible AP activity versus high basal AP activity) and, consequently, are likely to have different physiological $\mathrm{P}$ statuses despite being exposed to identical ambient concentrations of DIP (Mackey et al., 2007). Finally, the molar ratio of $\mathrm{NO}_{3}^{-}$: DIP drawdown calculated as the change in $\mathrm{NO}_{3}^{-}$divided by the change in DIP during the bloom was $\sim 5: 1$ (or equivalently 16:3.2), suggesting that approximately threefold more $\mathrm{P}$ was taken up than needed for photosynthesis based on the Redfield ratio of 16:1. Luxury P uptake along with the capacity for high AP activity in some species may serve to prevent $\mathrm{P}$ limitation when sudden pulses of $\mathrm{N}$ are encountered, such as following upwelling. This may provide certain species with a competitive edge as blooms begin to form.

It is interesting that despite the large input of $\mathrm{NO}_{3}^{-}$from upwelling during most of the year, phytoplankton in this region are still primarily limited by $\mathrm{NO}_{3}^{-}$, with $\mathrm{P}$ and other nutrients 

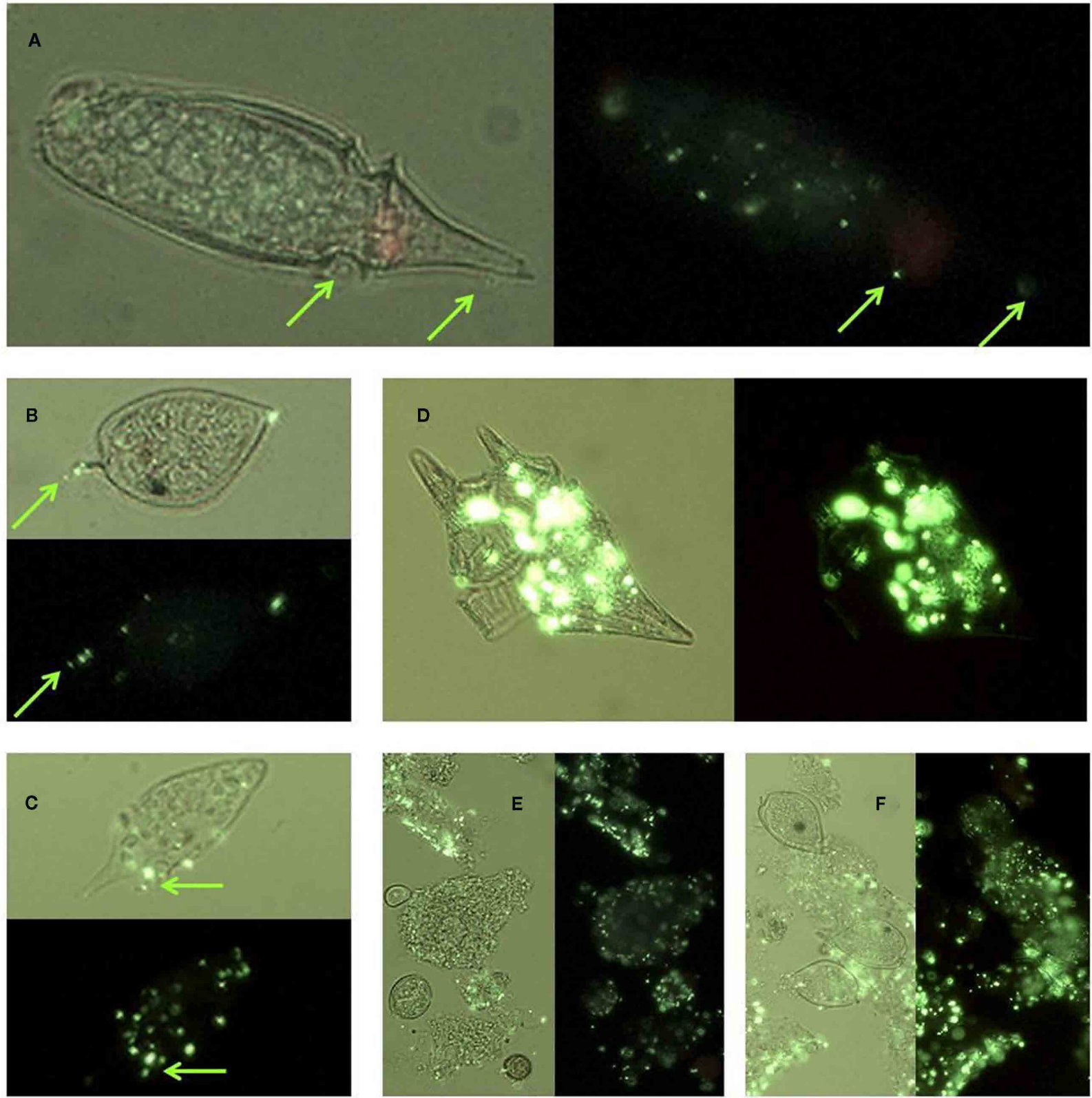

FIGURE 10 | Micrographs showing ELF labeled bacteria: (A) on the surface of an Oxyphysis cell, (B) on the surface of a Prorocentrum micans cell; (C) on the surface of an unidentified dinoflagellate cell (D) associated with lysed Ceratium furca cell debris, (E) associated with particulate material, (F) associated with particulate material and aggregated cells of $\boldsymbol{P}$ micans. Cells are shown under UV illumination with visible light on (light background) and off (dark background). Green arrows in (A-C) indicate the location of bacterial cells. like Fe (Hutchins and Bruland, 1998) and silica (Kudela and Dugdale, 2000) typically forming a second tier of limiting nutrients. Because phytoplankton require $\mathrm{N}$ and $\mathrm{P}$ at a relatively constant ratio (Redfield et al., 1963), high $\mathrm{NO}_{3}^{-}$concentrations relative to $\mathrm{P}$ concentrations would be expected to induce $\mathrm{P}$ limitation. We suggest that highly efficient recycling of $\mathrm{P}$ between particulate (e.g., cell) and dissolved fractions permits phytoplankton to satisfy their $\mathrm{P}$ demands, allowing them to avoid severe growth limitation by $\mathrm{P}$. The transfer of $\mathrm{P}$ to the dissolved organic fraction is likely a key step in the $\mathrm{P}$ cycling in this environment because it allows a portion of the $\mathrm{P}$ to remain in the euphotic zone where it is accessible to phytoplankton for a longer period of time, rather than sinking in cell aggregates. DOP has a longer turnover time than DIP; in addition to requiring enzymes for hydrolysis, a portion of $\mathrm{P}$ in the dissolved organic pool consists of compounds that are more resistant to degradation (Paytan et al., 2003). Together, these characteristics may allow DOP to sustain phytoplankton growth, albeit at a slower pace than DIP. This effect may have been suggested by the growth 


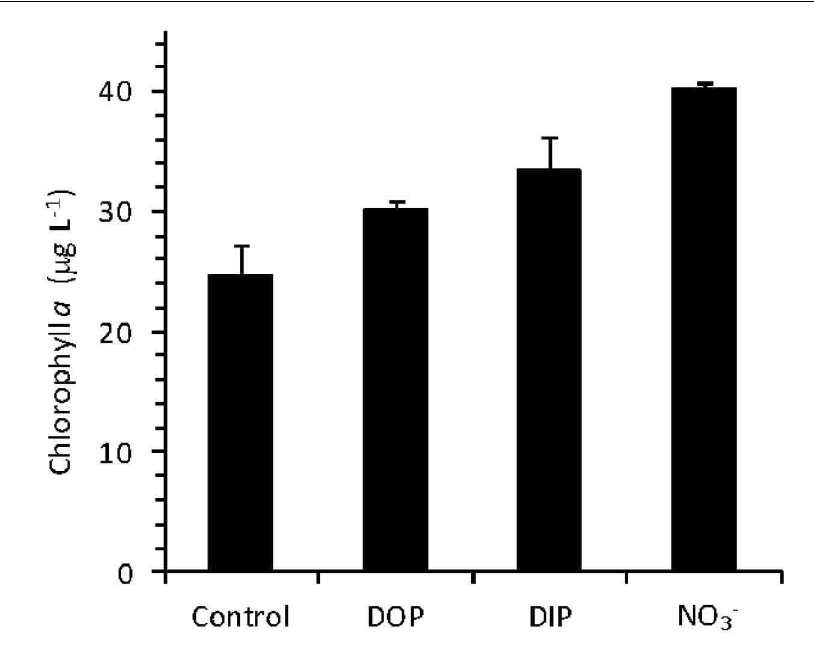

Nutrient addition treatment

FIGURE 11 | Growth of phytoplankton in response to added nutrients during an incubation experiment after $30 \mathrm{~h}$. $\mathrm{NO}_{3}^{-}$caused the strongest growth response (Mackey et al., 2010), followed by DIP, and SRP.

Growth in all three nutrient treatments was significantly different from the untreated control $(p<0.05)$.

responses in the incubation experiment, where addition of DIP led to slightly greater phytoplankton growth than DOP, although the values were not statistically significantly different from each other at $p<0.05$ (Figure 11). Therefore, whereas DIP gets consumed rapidly during growth and luxury uptake, DOP may represent a more sustainable, steady source of $\mathrm{P}$ nutrition for cells that can be accessed as needed.

In some strains of phytoplankton phosphatase activity is induced when ambient DIP concentrations are low, however, in other species phosphatase activity may be constitutive or less sensitive to ambient DIP levels (Kuenzler and Perras, 1965). In general our data do not suggest that ELF labeling is strongly controlled by DIP levels or the ratio of $\mathrm{NO}_{3}^{-}$: DIP in the RTI region of Monterey Bay over the time scales examined in this study, although there are exceptions for certain groups. For example, the labeling of diatoms did decrease slightly under high ambient DIP levels (and high DIP:DOP ratios, Figure 4) on October 14. The ELF labeling of diatoms appeared to be more sensitive to DOP levels than to DIP levels based on correlations within our data (Figure 7), suggesting that DOP availability could be a factor that regulates diatoms AP expression in addition to DIP levels. As DIP declined and DOP accumulated during upwelling relaxation (low DIP:DOP), succession occurred within the phytoplankton community, where bloom forming dinoflagellates with consistently high labeling came to outnumber diatoms despite their inducible AP activity.

Ruttenberg and Dyhrman (2005) discuss possible explanations for why phytoplankton might express inducible AP activity when ambient DIP concentrations are high. They suggest that P limitation in microenvironments, the nutritional history of the cell, and the relative competitiveness of each species for DIP can all contribute to an organism's P status. For each species, the last mechanism depends on the phosphate uptake kinetics and physiological $\mathrm{P}$ requirements of the cells, as well as the rate at which DIP gets regenerated in the environment. Together these factors can lead a cell to experience P stress under relatively high DIP conditions if they are unable to satisfy their $\mathrm{P}$ requirements during competition with other cells.

We suggest that in contrast to inducible AP activity, high basal AP activity may have different underlying causes. The high basal expression of AP activity, as observed in the HAB-forming dinoflagellates in the RTI, may offer a competitive advantage to cells when large pulses of $\mathrm{NO}_{3}^{-}$suddenly become available. This is because there is no lag time in their ability to access the DOP pool, whereas species with inducible AP (e.g., diatoms in this study) must wait to use this source of $\mathrm{P}$ until AP proteins are synthesized. Therefore, in upwelling regions where $\mathrm{P}$ is rapidly transferred between different pools and high DIP concentrations can be transient and depleted quickly, retaining high basal AP activity may confer a competitive advantage despite the energetic tradeoff of maintaining the enzyme. The mechanism by which cells maintain high basal rates of AP activity could be due to different AP encoding genes that are differentially regulated and expressed. For example, phoX encodes an AP enzyme widely distributed in marine bacteria that is inducible only under conditions of phosphate starvation, whereas phoA encodes an AP enzyme that can also be expressed in response to $C$ limitation (Sebastian and Ammerman, 2009), leaving open the possibility that environmental factors other than DIP concentration can lead to high basal AP rates in certain species. In addition, constitutive expression of acid phosphatases is known to occur in bacteria (Kuenzler and Perras, 1965). Maintenance of high basal AP activity, whether through constitutive expression or due to different classes of AP enzymes, may also help explain why red tides are often associated with low ratios of $\mathrm{NO}_{3}^{-}$: DIP (Hodkiss and Lo, 1997). By accessing the DOP pool when DIP uptake becomes energetically unfavorable (e.g., due to diffusion limitation or physiological characteristics), these cells would be able to exhaust a larger portion of the $\mathrm{NO}_{3}^{-}$ without simultaneously exhausting the DIP pool, thereby leading to lower $\mathrm{NO}_{3}^{-}$: DIP ratios in seawater.

During our sampling, the RTI region was populated by a number of localized, intense blooms, the largest of which was dominated by $C$. balechii and $C$. furca (Figure 6). In addition to expressing AP activity, some strains of Ceratium are known to alter their morphological and metabolic traits in response to $\mathrm{P}$ availability. Smalley et al. (2003) investigated the affect of P starvation in cultures of C. furca. Under P limitation (but not $\mathrm{N}$ limitation), a bimodal cell size distribution emerged in which larger cells became prominent, raising the possibility that $\mathrm{P}$ stress could encourage sexual reproduction in these cells. Additionally, under either $\mathrm{P}$ or $\mathrm{N}$ limitation (e.g., at intracellular $\mathrm{N}: \mathrm{P}$ ratios $>19: 1$ or $<7: 1$ ), cells transitioned from autotrophic to mixotrophic growth modes. Although minor size differences were observed in C. balechii in our samples, there was no consistent trend between cell size and the extent ELF labeling or DIP concentration. However, we did observe feeding vacuoles in several specimen of C. balechii (Figures 9G,H), suggesting that mixotrophy may help Ceratium satisfy its nutritional requirements in the RTI region of Monterey Bay. These qualitative observations suggest that although Ceratium 
cells had very high AP activity, they were probably limited by $\mathrm{N}$, with $\mathrm{P}$ availability acting as a regulating (rather than limiting) nutrient.

\section{BACTERIAL AP ACTIVITY}

The extensive amount of AP activity observed in bacterial cells suggests three potentially important roles for bacteria in facilitating the turnover of organic P in Monterey Bay. First, their association with particulate material and cell debris demonstrates the critical function they perform in aggregating and breaking down organic materials during upwelling relaxation, and the sharp, rapid decline in DOC observed during upwelling relaxation (Figure $3 \mathbf{H}$ ) could indicate heterotrophic bacterial utilization of this abundant $\mathrm{C}$ source. Bacteria generate extracellular polysaccharides that encourage flocculation of algal cells (Passow et al., 1994), which may facilitate the degradation of blooms as they decline. Flocculation also enhances sinking rates of phytoplankton cells, providing an important mechanism by which the non-regenerated portion of $\mathrm{C}$ and $\mathrm{P}$ fixed during a bloom are exported from surface waters.

Second, in a decaying bloom, bacteria could support additional primary and secondary production and re-inject $\mathrm{P}$ into the food web through their AP activity. Bacteria may employ AP activity to access $\mathrm{P}$ or $\mathrm{C}$ from organic molecules, and it is not clear if the bacteria in our samples expressed the enzyme to satisfy their needs for $\mathrm{P}, \mathrm{C}$, or both. In the microbial loop, bacteria take up and incorporate organic $\mathrm{C}$ into their cellular biomass, thereby returning it to the classical grazing food web (Azam et al., 1983). If the primary function of bacterial AP activity observed in Monterey Bay was to support bacterial $\mathrm{C}$ requirements, the regenerated orthophosphate created as a byproduct of bacterial AP activity would be available to support additional rounds of primary production by phytoplankton. In this case, $\mathrm{P}$ would re-enter the grazing food web at the level of primary producers. Alternately, if bacterial AP activity resulted in bacterial assimilation of both $\mathrm{C}$ and $\mathrm{P}$, then $\mathrm{P}$ would instead be provided to higher trophic levels via direct grazing on bacteria. In both cases, organic $\mathrm{C}$ would also be re-captured and made available to higher trophic levels, as was evident from the rapid consumption of DOC following the bloom (Figure 3 ). More work is needed to quantify bacterial DOC uptake in this and other upwelling systems.

The third possible role for bacteria in the $\mathrm{P}$ cycle of Monterey Bay is based on our observation that some bacteria affixed to the surfaces of intact phytoplankton cells expressed AP activity (Figures 10A-C), suggesting that a close relationship may exist where one or both organisms benefit. Microbial consortia between bacteria and algal cells are a well studied phenomenon, particularly for phytoplankton species that form HABs (Doucette, 1995; Paerl and Pinckney, 1996). Many suggestions have been put forward to explain the causes and outcomes of these close interactions, including possible roles in toxin production (Kodama et al., 2006), regulation of mating and cyst formation (Sawayama et al., 1993), and nitrogen acquisition (Foster et al., 2011). It is also possible that the bacteria we observed associated with intact phytoplankton cells could have been feeding on individuals that were physiologically unfit. However, if the intact phytoplankton cells we observed represent healthy individuals, then their close associations with bacteria may indicate a beneficial relationship that constitutes another pathway in the biological cycling of P. As discussed above, bacterial AP activity could serve to provide bacteria with $\mathrm{P}, \mathrm{C}$, or both. The interaction between bacteria and phytoplankton in Monterey Bay could be mutualistic if bacteria utilize organic $\mathrm{C}$ exuded from phytoplankton and in turn provide phytoplankton with regenerated orthophosphate, or commensal if the bacteria retain $\mathrm{P}$ (and C) from the exudates.

\section{CONCLUSION}

The RTI of Monterey Bay is a region with dynamic changes in nutrient inventories and where diverse phytoplankton species co-exist. Following upwelling, a pulse of DIP and $\mathrm{NO}_{3}^{-}$was consumed rapidly as phytoplankton bloomed. DOP accumulated as upwelling relaxed and the bloom declined, likely due to phytoplankton excretion and sloppy grazing as has been observed in other upwelling regions (Ruttenberg and Dyhrman, 2005). Although phytoplankton in this region expressed high AP activity, the phytoplankton growth induced by DIP and DOP in a bottle incubation experiment was lower than for $\mathrm{NO}_{3}^{-}$. Transfer of $\mathrm{P}$ to the dissolved organic pool may allow $\mathrm{P}$ to remain in surface waters longer and be used by phytoplankton at a steadier pace than DIP, which is consumed quickly through luxury uptake and depleted rapidly from the water.

Diatom and dinoflagellate populations were identified in similar abundances prior to upwelling, but dinoflagellates became more abundant during upwelling and relaxation. Diatom alkaline phosphatase (AP) activity was responsive to ambient DIP and DOP concentrations. In contrast, dinoflagellates showed high basal rates of AP activity regardless of DIP (or DOP) levels, which may have conferred a competitive advantage by helping them avoid secondary limitation for $\mathrm{P}$ when $\mathrm{N}$ levels were high following upwelling. Diatom species were distributed uniformly among the stations, whereas some dinoflagellate species formed spatially localized blooms within the RTI region. The largest of these blooms comprised Ceratium cells, which expressed high AP activity and appeared to adopt a mixotrophic growth mode as they bloomed. A considerable amount of AP activity was observed in bacterial cells associated with lysed cell debris and particulate material, suggesting an important role for bacteria in the regeneration of $\mathrm{P}$ and possibly $\mathrm{C}$ from cell biomass following the bloom. Bacteria associated with intact phytoplankton cells were also observed expressing AP activity, and could indicate a previously unrecognized algal-bacterial relationship that facilitates the $\mathrm{P}$ cycle at an intercellular level. Our results suggest that $\mathrm{P}$ is a regulating, rather than limiting, nutrient for HABforming phytoplankton in Monterey Bay, and that cells adopt a number of different strategies (AP activity, luxury DIP uptake, mixotrophy, bacterial interactions) to acquire $\mathrm{P}$ from this dynamic environment.

\section{ACKNOWLEDGMENTS}

We thank the Bhaya and Grossman Labs (Carnegie Institution for Science) for use of their microscope, L. Smolenska (Invitrogen) for technical advice pertaining to phytoplankton ELF labeling, R. Franks for assistance with instrumentation, and E. 
Rienecker for piloting the boat and provided assistance at sea. This manuscript benefited from thoughtful review comments from L. Moore, B. Jenkins, and J. B. Sylvan. Thanks also to G. Pitcher (Department of Agriculture, Forestry and Fisheries, South Africa), J. Lane (University of California, Santa Cruz), and R. Kudela (University of California, Santa Cruz) for discussions

\section{REFERENCES}

Anderson, D. M., Glibert, P. M., and Burkholder, J. M. (2002). Harmful algal blooms and eutrophication: nutrient sources, composition, and consequences. Estuaries 25, 704-726.

Azam, F., Fenchel, T., Field, J. G., Gray, J. S., Meyer-Reil, L. A., and Thingstad, F. (1983). The ecological role of water-column microbes in the sea. Mar. Ecol. Prog. Ser. 10, 257-263.

Barka, T. (1960). A simple azo-dye method for histochemical demonstration of acid phosphatases. Nature 248-249.

Bjorkman, K., and Karl, D. M. (1994). Bioavailability of inorganic and organic phosphorus compounds to natural assemblages of microorganisms in Hawaiian coastal waters. Mar. Ecol. Prog. Ser. 111, 265-273.

Bronk, D. A., and Ward, B. B. (1999). Gross and net nitrogen uptake and DON release in the euphotic zone of Monterey Bay, California. Limnol. Oceanogr. 44, 573-585.

Chavez, F. P. V, and Toggweiler, J. R. (1995). "Physical estimates of global new production: the upwelling contribution," in Upwelling in the Ocean: Modern Processes and Ancient Records, eds C. P. Summerhayes, K.C. Emeis, M. V. Angel, R. L. Smith, and B. Zeitzschel (New York: John Wiley), 313-320.

Chavez, F. P., and Messie, M. (2009). A comparison of eastern boundary upwelling ecosystems. Prog. Oceanogr. 83, 80-96.

Dagg, M. J. (1974). Loss of prey body contents during feeding by an aquatic predator. Ecology 55, 903-906.

D’Elia, C. F., Steudler, P. A., and Corwin, N. (1977). Determination of total nitrogen in aqueous samples using persulfate digestion. Limnol. Oceanogr. 22, 760-764.

Doucette, G. J. (1995). Interactions between bacteria and harmful algae: a review. Nat. Toxins 3, 65-74.

Dugdale, R. C., and Goering, J. J. (1967). Uptake of new and regenerated forms of nitrogen in primary productivity. Limnol. Oceanogr. 12, 196-206.

Dyhrman, S. D., and Ruttenberg, K. C. (2006). Presence and regulation of alkaline phosphatase activity in eukaryotic phytoplankton from the coastal ocean: implications for dissolved organic phosphorus remineralization. Limnol. Oceanogr. 51, 1381-1390.

Dyhrman, S. T., and Palenik, B. (1999). Phosphate stress in cultures and field populations of the dinoflagellate prorocentrum minimum detected by a single-cell alkaline phosphatase assay. Appl. Environ. Microbiol. 65, 3205-3212.

Dyhrman, S. T., and Palenik, B. (2001). A single-cell immunoassay for phosphate stress in the dinoflagellate Prorocentrum minimum (Dinophyceae). J. Phycol. 37, 400-410.

Falkowski, P. G. (1997). Evolution of the nitrogen cycle and its influence on the biological sequestration of $\mathrm{CO}_{2}$ in the ocean. Nature 387, 272-275.

Foster, R. A., Kuypers, M. M. M., Vagner, T., Paerl, R. W., Musat, N., and Zehr, J. P. (2011). Nitrogen fixation and transfer in open ocean diatomcyanobacterial symbioses. ISME J. 5, 1484-1493.

Fourqurean, J. W., Jones, R. D., and Zieman, J. C. (1993). Process influencing water column nutrient characteristics and phosphorus limitation of phytoplankton biomass in Florida Bay, FL, USA: inferences from spatial distributions. Estuar. Coast Shelf Sci. 36, 295-314.

Gomez, F., Claustre, H., and Souissi, S. (2008). Rarely reported dinoflagellates of the genera Ceratium, Gloeodinium, Histioneis, Oxytoxum and Prorocentrum (Dinophyceae) from the open southeast Pacific Ocean. Rev. Biol. Mar. Oceanogr. 43, 25-40.

Hansen, H. P., and Koroleff, F. (1999). "Determination of nutrients," in Methods of Seawater Analysis, eds K. Grasshoff, K. Cremling, and M. Erhardt (Weinheim: Wiley-Vch Verlag), 159-228.

Harrison, P. J., Hu, M. H., Yang, Y. P., and Lu, X. (1990). Phosphate limitation in estuarine and coastal waters of China. J. Exp. Mar. Biol. Ecol. 140, 79-87.

Hernández-Becerril, D. U., and AlonsoRodríguez, R. (2004). Study of the marine planktonic dinoflagellate Ceratium divaricatum (Dinophyceae), a confused and considerably variable species. Phycological Res. 52, 346-354.

of Ceratium taxonomy. This research was supported by NSFOCE grant 0961555 to Adina Paytan, and a grant from the Monterey Bay Aquarium Research Institute to Adina Paytan and John P. Ryan. Katherine R. M. Mackey was supported by the Department of Energy (DOE) Global Change Education Program.

Hoagland, P., and Scatasta, S. (2006) "The economic effects of harmful algal blooms," in Ecology of Harmful Algae. Ecology Studies Series, Chap. 29, eds E. Graneli and J. Turner (Dordrecht: Springer-Verlag), 391-401.

Hodkiss, I. J., and Lo, K. C. (1997). Are changes in N:P ratios in coastal waters the key to increased red tide blooms? Hydrobiologia 352, 141-147.

Hutchins, D. A., and Bruland, K. W. (1998). Iron-limited diatom growth and Si:N uptake ratios in a coastal upwelling. Nature 393, 561-564.

Jessup, D. A., Miller, M. A., Ryan, J. P., Nevins, H. M., Kerkering, H. A., Mekebri, A., Crane, D. B., Johnson, T. A., and Kudela, R. M. (2009). Mass stranding of marine birds caused by a surfactant-producing red tide. PLoS ONE 4, e4550. doi:10.1371/journal.pone.0004550

Kirchman, D. L., Meon, B., Cottrell, M. T., Hutchins, D. A., Weeks D., and Bruland, K. W. (2000). Carbon versus iron limitation of bacterial growth in the California upwelling regime. Limnol. Oceanogr. 45, 1681-1688.

Kodama, M., Doucette, G. J., and Green, D. H. (2006). Relationships between bacteria and harmful algae. Ecol. Harmful Algae 189, 243-255.

Krom, M. D., Kress, N., Brenner, S. and Gordon, L. I. (1991). Phosphorus limitation of primary productivity in the eastern Mediterranean Sea. Limnol. Oceanogr. 36, 424-432.

Kudela, R. M., and Chavez, F. P. (2000). Modeling the impact of the $1992 \mathrm{El}$ Niño on new production in Monterey Bay, California. Deep Sea Res. Part II Top. Stud. Oceanogr. 47, 1055-1076.

Kudela, R. M., and Dugdale, R. C. (2000). Nutrient regulation of phytoplankton productivity in Monterey Bay, CA. Deep Sea Res. Part II Top. Stud. Oceanogr. 47, 1023-1053.

Kudela, R. M., Lane, J. Q., and Cochlan, W. P. (2008). The potential role of anthropogenically derived nitrogen in the growth of harmful algae in California, USA. Harmful Algae 8, 103-110.

Kudela, R. M., Seeyave, S., and Cochlan, W. P. (2010). The role of nutrients in regulation and promotion of harmful algal blooms in upwelling systems. Prog. Oceanogr. 85, 122-135.

Kuenzler, E. J., and Perras, J. P. (1965). Phosphatases of marine algae. Biol. Bull. 128, 271-284.

Lampert, W. (1978). Release of dissolved organic carbon by grazing zooplankton. Limnol. Oceanogr. 23, 831-834.

Lomas, M. W., Swain, A., Shelton, R. and Ammerman, J. W. (2004). Taxonomic variability of phosphorus stress in Sargasso Sea phytoplankton. Limnol. Oceanogr. 49, 2303 2310.

Mackey, K. R. M., Labiosa, R. G., Calhoun, M., Street, J. H., and Paytan, A. (2007). Phosphorus availability, phytoplankton community dynamics, and taxon-specific phosphorus status in the Gulf of Aqaba, Red Sea. Limnol. Oceanogr. 52, 875-885.

Mackey, K. R. M., Bristow, L., Parks, D. R., Altabet, M. A., Post, A. F., and Paytan, A. (2011). The influence of light on nitrogen cycling and the primary nitrite maximum in a seasonally stratified sea. Prog. Oceanogr. 91, 545-560.

Mackey, K. R. M., Rivlin, T., Grossman, A. R., Post, A. F., and Paytan, A. (2009). Picophytoplankton responses to changing nutrient and light regimes during a bloom. Mar. Biol. 156, 1531-1546.

Mackey, K. R. M., van Djiken, G., Mazloom, S., Erhardt, A. M., Ryan, J., Arrigo, K., and Paytan, A. (2010). Influence of atmospheric nutrients on primary productivity in a coastal upwelling region. Global Biogeochem. Cycles 24, GB4027.

Mayahara, H., Hirano, H., Saito, T., and Ogawa, K. (1967). The new lead citrate method for the ultracytochemical demonstration of activity of non-specific alkaline phosphatase (orthophosphoric monoester phosphohydrolase). Histochem. Cell Biol. 11, 88-96.

Meave del Castillo, M. E., Zamudio Resendiz, M. E., Okolodkov, Y. B., and Salgado Ugarte, I. H. (2003). Ceratium balechii sp. nov. (Dinophyceae: Gonyaulacales) from the Mexican Pacific. Hidrobiolo' gica 13, 75-91. 
Monaghan, E. J., and Ruttenberg, K. C. (1999). Dissolved organic phosphorus in the coastal ocean: reassessment of available methods and seasonal phosphorus profiles from the Eel River Shelf. Limnol. Oceanogr. 44, 1702-1714.

Nicholson, D., Dyhrman, S., Chavez, F., and Paytan, A. (2006). Alkaline phosphatase activity in the phytoplankton communities of Monterey Bay and San Francisco Bay. Limnol. Oceanogr. 51, 874-883.

Paerl, H. W., and Pinckney, J. L. (1996). A mini-review of microbial consortia: their role in aquatic production and biogeochemical cycling. Microb. Ecol. 31, 225-247.

Passow, U., Alldredge, A. L., and Logan, B. E. (1994). The role of particulate carbohydrate exudates in the flocculation of diatom blooms. Deep Sea Res. Part I Oceanogr. Res. Pap. 41, 335-357.

Paytan, A., Cade-Menun, B, McLaughlin, K., and Faul, K. L. (2003). Selective phosphorus regeneration of sinking marine particles: evidence from 31P-NMR. Mar. Chem. 82, 55-70.

Pennington, J. T., and Chavez, F. (2000). Seasonal fluctuations of temperature, salinity, nitrate, chlorophyll, and primary production at station H3/M1 over 1989-1996 in Monterey Bay, CA, Deep Sea Res. Part II Top. Stud. Oceanogr. 47, 947-973.

Pitcher, G., and Probyn, T. A. (2011). Anoxia in southern Benguela during the autumn of 2009 and its linkage to a bloom of the dinoflagellate Ceratium balechii. Harmful Algae 11, 23-32.

Redfield, A., Ketchum, B. H., and Richards, F. A. (1963). "The influence of organisms on the composition of seawater," in The sea, Vol. 2, ed. M. N. Hill (New York: Wiley Interscience), 26-77.

Ruttenberg, K. C., and Dyhrman, S. T. (2005). Temporal and spatial variability of dissolved organic and inorganic phosphorus, and metrics of phosphorus bioavailability in an upwelling-dominated coastal system. J. Geophys. Res. 110, C10S13.

Ryan, J. P., Fischer, A. M., Kudela, R. M., Gower, J. F. R., King, S. A., Marin, R. III, and Chavez, F. P. (2009). Influences of upwelling and downwelling winds on red tide bloom dynamics in Monterey Bay, California. Cont. Shelf Res. 29, 785-795.

Ryan, J. P., Gower, J. F. R., King, S. A., Bissett, W. P., Fischer, A. M., Kudela, R. M., Kolber, Z., Mazzillo, F., Rienecker, E. V., and Chavez, F. P. (2008). A coastal ocean extreme bloom incubator. Geophys. Res. Lett. 35, L12602.

Ryan, J. P., Greenfield, D., Marin, R., Preston, C., Roman, B., Jensen, S., Pargett, D., Birch, J., Mikulski, C., Doucette, G., and Scholin, C. (2011). Harmful phytoplankton ecology studies using an autonomous molecular analytical and ocean observing network. Limnol. Oceanogr. 56, 1255-1272.

Sawayama, S., Sako, Y., and lshida, Y. (1993). "Bacterial inhibitors for the mating reaction of Alexandrium catenella (Dinophyceae)," in Toxic Phytoplankton Blooms in the Sea eds T. J. Smayda and Y. Shimizu (Amsterdam: Elsevier Sci Pub1 BV), 177-181.

Sebastian, M., and Ammerman, J. W. (2009). The alkaline phosphatase PhoX is more widely distributed in marine bacteria than the classical PhoA. ISME J. 3, 563-572.

Smalley, G. W., Coats, D. W., and Stoecker, D. K. (2003). Feeding in the mixotrophic dinoflagellate Ceratium furca is influenced by intracellular nutrient concentrations. Mar. Ecol. Prog. Ser. 262, 137-151.

Sundareshwar, P. V., Morris, J. T., Koepfler, E. K., and Fornwalt, B. (2003). Phosphorus limitation of coastal ecosystem processes. Science 299, 563-565.

Sylvan, J. B., Dortch, Q., Nelson, D. M., Maier Brown, A. F., Morrison, W., and Ammerman, J. W (2006). Phosphorus limits phytoplankton growth on the Louisiana Shelf during the period of hypoxia formation. Environ. Sci. Technol. 40, 7548-7553.

Toledo, G., and Palenik, B. (1997). Synechococcus diversity in the California current as seen by RNA polymerase (rpoC1) gene sequences of isolated strains. Appl. Environ. Microbiol. 63, 4298-4303.

Tomas, C. R. (1997). Identifying Marine Phytoplankton. New York, NY: Academic Press.

Valderrama, J. C. (1981). The simultaneous analysis of total nitrogen and total phosphorus in natural waters. Mar. Chem. 10, 109-122.

Wollast, R. (1991). “The coastal organic carbon cycle: fluxes, sources and sinks," in Ocean Margin Processes in Global Change, eds R. C. F. Mantoura, J. M. Martin, and R. Wollast (Chichester: Wiley), 365-382.

Worden, A. P. (2006). Picoeukaryote diversity in coastal waters of the Pacific Ocean. Aquat. Microb. Ecol. 43, 165-175.

Conflict of Interest Statement: The authors declare that the research was conducted in the absence of any commercial or financial relationships that could be construed as a potential conflict of interest.

Received: 02 November 2011; accepted: 18 January 2012; published online: 07 February 2012.

Citation: Mackey KRM, Mioni CE, Ryan JP and Paytan A (2012) Phosphorus cycling in the red tide incubator region of Monterey Bay in response to upwelling. Front. Microbio. 3:33. doi: 10.3389/fmicb.2012.00033

This article was submitted to Frontiers in Aquatic Microbiology, a specialty of Frontiers in Microbiology.

Copyright (C) 2012 Mackey, Mioni, Ryan and Paytan. This is an open-access article distributed under the terms of the Creative Commons Attribution Non Commercial License, which permits noncommercial use, distribution, and reproduction in other forums, provided the original authors and source are credited. 